\title{
Investigating Gender Differences on the Students' Attitudes and Motivation toward English Learning
}

\author{
Agus Husein As Sabiq \\ English Education Department, IAIN Purwokerto, Indonesia \\ husein@iainpurwokerto.ac.id \\ Siti Hariroh Arwi \\ English Education Department, IAIN Purwokerto, Indonesia \\ hariroharwi@gmail.com \\ Anisatul Khusna \\ English Education Department, IAIN Purwokerto, Indonesia \\ anisatulkhusna1@gmail.com \\ Dhelvy Ulfa Shita Adifia \\ English Education Department, IAIN Purwokerto, Indonesia \\ dhelvyulfasa@gmail.com \\ Dhea Zabana Qothrun Nada \\ English Education Department, IAIN Purwokerto, Indonesia \\ nadadhea25@gmail.com
}

\begin{abstract}
Some researchers have researched to explore the effects of gender differences on learning outcomes. However, the interrelatedness of gender differences to attitudes and motivation needs to explore and investigate more. Thus, this study aimed to investigate the students' attitudes toward the English language and their motivation toward English language teaching based on gender differences in a state junior high school in Banyumas Regency, Central Java, Indonesia. There were 38 male and 32 female students who participated in this research. This research used a survey adapted from the Attitude/Motivation Test Battery (AMTB) and interviews in collecting the data. The researchers
\end{abstract}


employed descriptive statistics and MANOVA for quantitative data and the Miles and Huberman model for qualitative data analysis. The findings showed a significant difference and effect of gender differences on the students' attitudes and motivation. Both male and female students revealed moderately high attitudes and motivation. However, female students showed a higher average score of the survey result. Less practice in real-life communication and limited exposure was the reason why the male students' have lower results in their attitudes and motivation toward English learning. Thus, providing authentic materials and exposure became some of the key points to improve meaningful learning experiences.

Keywords: Attitude; English Learning; Gender Differences; Motivation;

\section{INTRODUCTION}

English is first learned at school in the Indonesian sense as a foreign language and replaced the Netherlands after the Dutch colonial secondary school (Dardjowidjojo, 2000). Since then, in different education stages in Indonesia, English has been taught as a foreign language. However, English has never legally been used, not to speak as a second language, as a communication tool. Indonesians seldom speak English outside the academic environments of the classroom. The lack of actual communication can lead to Indonesians using the non-standard type of English (Kirkpatrick, 2011).

Learners demonstrate varying degrees of proficiency, and individual variations between foreign language learners can affect foreign language learning. English as a foreign language should take account of those considerations that can hinder the language's proficiency. The servant wishes to inculcate character traits in pupils as well as increase their capacity to grasp English (Gusmuliana, et. al, 2020). Some variables influence language learning, such as input content and quantity, age, personality, skills, motivation, and anxiety (Bidin et al., 2009; Gömleksiz, 2010). Since some adult learners are more successful than others at learning English as a foreign language, researchers have looked into human traits as predictors of successful foreign language acquisition.

The learner mindset issue is recognized as an essential influence influencing language learning (Fakeye, 2010). Aside from viewpoints and values, students' attitudes toward learning have a noticeable impact on their actions and, as a result, their success (Kara, 2009). Students who are 
Agus Husein As Sabiq, et.al: Investigating Gender Differences on the Students' Attitudes and Motivation toward English Learning - 237

excited about language learning tend to have more positive attitudes towards language learning.

Attitudes toward target language culture have been studied within the context of the broader concept of motivation. According to Gusmuliana (2020), motivation is one of the most important factors that can motivate students to speak English, and instructors' fans can assist encourage pupils to speak English. Motivation is most likely one of the most important determinants of people's behavior (Filgona et al., 2020). The desire to learn is closely related to the principle that previous actions to receive reward are more likely to be replicated than future behaviors to obtain reinforcement or punishment. The heart of learning experiences is motivation to learn. The guiding force that influences students' strenuous efforts is motivation to understand (Dörnyei, 2003).

Concerns about students' attitudes and motivation are not recent. Students generally need a proper attitude, since apathy can lead to pessimism and little or no attempt at participating in the learning process. According to the social learning view, students voluntarily participate in the learning process while being guided by the 'master' (Ahmad et al., 2014)

Gender is a basic categorization that is recognized and followed in all human cultures as a source of defining a person and social identity. Gender gaps are thought to affect mood and motivation, as well as the learning process. Nowadays, scholars are eager to assign gender differences to sociocultural influences that place role models on females and promote a favorable outlook toward second language learning. Motivation research on gender disparities in a foreign language learning setting has shown that females are more encouraged to study foreign languages than people (Csizer \& Dornyei, 2005; Heinzmann, 2009; Qian, 2015; Ruyffelaert \& Hadermann, 2012).

Some research has been conducted on students' attitudes and motivation based on gender perspectives. Aldosari (2014) investigated the differences between 50 university students in the attitudinal and motivational patterns in EFL learning. The results showed that female students have better positive attitudes and higher motivation. By researching a specific skill, Murtafi'ah \& Putro (2020) also found that females higher attitude in both academic and recreational reading than males. A similar pattern was also recorded by Frijters et al. (2019) that reading motivation and reading performance were affected by gender disparities. Another study (Akdemir, 2019) employed a mini AMTB to determine the students' willingness to learn and revealed that females have a more meaningful willingness to listen L2. Although many 
researchers found the superiority of female students, several studies reported the different findings that there is no significant effect of gender disparities on attitudes and motivation toward EFL learning (Abu-rabia, 1997; Bacon, 1992; Niaz et al., 2018). However, this study explores the students' attitudes toward the English language and their motivation toward English language teaching based on gender differences in a state junior high school in Banyumas Regency, Central Java, Indonesia

This study aimed to investigate students' attitudes and motivation based on their gender differences and to determine the level of attitudes and motivation. The research questions of this paper are therefore formulated as follow:

1. How are the students' attitudes and motivation toward English language teaching based on their gender differences?

2. What are the levels of attitudes and motivation toward English language teaching based on their gender differences?

\section{THEORETICAL FRAMEWORK} Attitude

Attitude is characterized by a well-established viewpoint (positive or negative response) or way of thinking and behavior (Ajzen \& Fishbein, 2000; Erwin, 2001). Most people now agree that an attitude reflects an evaluative synthesis of knowledge and influences experienced objects. Besides, attitudes are evaluative assessments incorporating these cognitive/affective responses to summarize them. These assessed abstractions differ in intensity, which in turn affect stability, resilience, and continuity in behavior (Holland et al., 2002; Petty et al., 2008). Attitude involves someone's likes or dislikes and assessing if someone or something is pleasant, bad, helpful, negative, useful, or invaluable (Saeed et al., 2014). Therefore, attitude pertains to the fields of effects and knowledge. Attitudes are essential elements that affect the academic skills of the learner and their attitudes to language learning to attain the objective language output. Positive and pessimistic views decide whether or not language learning is effective in the target language group.

The functional view states that behaviors are aimed at mediating between the internal needs of an individual (e.g. security and selfexpression) and external environments, which are packed with people and knowledge (Karthikeyan, 2017). Any behavior a person has can somehow allow him or her to fulfill his or her needs. According to Katz (1960, cited in Erwin, 2001), attitudes satisfied needs, and therefore attitudes functions, fell into four broad categories: the adaptive (or 
Agus Husein As Sabiq, et.al: Investigating Gender Differences on the Students' Attitudes and Motivation toward English Learning - 239

instrumental) function; the information function; a value (or egoexpressive) function; and an ego-defense function. The same mindset can serve somewhat different purposes, depending on who wears it and where it stands out.

Aspects of attitude include behavioral aspects of attitude, the cognitive aspect of attitude, and the emotional aspect of attitude. Kara (2009) claimed that good attitudes contribute to better conduct for research courses, with learners absorbing themselves and trying to learn more. It is often found that these children are keen to solve problems, gain the knowledge and skills that are valuable for their daily lives, and participate emotionally. The cognitive component of attitude concerns the convictions of language students regarding their comprehension of the language they study. Feng \& Chen (2009) stated that in the learning process, the mental component of behavior is an emotional process. Diverse emotional aspects influence it. The teacher and his students collaborate in different emotional events and different emotional fruits. Doing a course will allow students to say whether they like objects or scenarios around them or not. The inner thoughts and sentiments of FL learners affect their views and attitudes towards the target language (Choy \& Troudi, 2006).

Gardner (1985; 2005) developed a socio-educational foreign language model, namely the Attitude/Motivation Test Battery. This AMTB test distinguishes two attitudes (integrativeness and learning attitudes) from the third motivational component. The model shows that integrativeness and learning attitude are two associated factors, which enable people to learn a second language but are responsible for second language motivation.

The attitude of learning can be positive because the historical, cultural, and economic background can influence students' behaviors. It may also be a negative attitude; for example, some students dislike English and even its learning. This kind of student is therefore starting to demonstrate his harassment. Social relationships between members of the society include the area of language (Fatiha et al., 2014). The success of languages, particularly English, is linked to the attitude of the community towards the speaker of the languages. For these reasons language, social psychology has evolved into a field that is central to itself.

\section{Motivation}

In educational psychology, defining what it is to be motivated is quite simple: "to be motivated is to be moved to do something" (Ryan \& Deci, 2000; Winke, 2005). Motivation is a condition through which we 
behave, drive-in certain ways, and partake in such behaviors. Equally important to success are learning and motivation: learning allows us to gain new insights and abilities, which motivate us to demonstrate what we learned, and motivation provides the impetus for showing what we have learned. More motivated individuals generally reach higher levels (Elliott, 2000). An inner mechanism that energetically sustains a certain behavior and guides action is a motive (Reeve, 2005; Zlate \& Cucui, 2015). However, Reeve (2016) added that motivation could be inferred from its expression through a person's behavior, engagement, physiology, and self-report.

Gardner et al. (1985) characterized the motivation to learn a foreign language as a complex of buildings involving commitment and desire as well as a beneficial mindset for learning the language at hand in the socio-educational model of language acquisition. The socioeducational paradigm encouraged the idea that self-identification and identification with the language culture were crucial to the process of language learning.

Another significant factor influencing overall motivation is integrativeness. Gardner (2006) has described it as a complex construction that expresses interest in studying the L2 culture in a foreign language. Thus, the term refers to the attitudes towards foreign language learning and the category L2 in general and a desire of learners to communicate with L2 community members (Dörnyei, 2003). Attitudes towards the learning situation constitute the second component of Gardner's two-pronged theory of motivation.

In the TESOL context, Dörnyei (2003) offers an L2-motivation system consisting of three levels: level of the language, level of the student, and level of the condition of learning. The standard of languages relates to these facets of L2 culture and society and their "intelligence and pragmatism" for the learner. The motivation concept is closely related to other educational and psychological principles, including attention constructs, desires, objectives, and interests, all of which help stimulate students to learn and to participate in specific tasks and accomplish different objectives (Cook \& Artino Jr, 2016). Furthermore, Daskalovska et al. (2012) claimed that not only are those with innate learning capabilities the successful learners but those with some traits, most of which are motivated.

\section{Gender Differences}

From the 1980s onwards, Gender Studies have become more and more critical and in the 1990s. Butler (1989) recognized that gender is a social and cultural category in which the problem of the body is linked 
to daily social and cultural activities and discourses. Meanwhile, Litosseliti (2006) defines gender as male and female actions, beliefs, and attitudes; she argues that cultural constructions, collectively defined and alterable are the features assigned to make sexual differences. However, we have put this social category as "discourses of the multiplicities," to plan the courses and to consider the gender inequalities in education and possibilities for change (Castaneda-Pena, 2008).

Rubin (1975) has identified gender/sex as a series of structures whereby a culture converts biological sexuality into products of human interaction and fulfills these transformed sexual needs. Whereas sex, as we know it, is itself a social product, including gender identity, sexual attraction, and imagination, childhood conceptions. Sunderland (2000) llotes that the difference between "sex" and "gender" is normally made; the former indicates biology, while the latter is a social one.

Hunim (1989) uses the word 'gender' to refer to males' and females' cultural characteristics. This socio-cultural differentiation has fascinated researchers in most areas who tried to detect gender differences. The gender gaps in the SLA concerning SLA attitudes and test results, leamer/learning strategies, and classroom behavior, and performance awareness were concerned in social and psycholinguistic studies. Although sex and gender are interchangeably used, they are commonly viewed as synonymous. Nevertheless, sex is explained as either male or female, and both men and women may be called a certain gender.

The study of gender differences and language is an interdisciplinary academic field. Both have quite a strong relation. Flotow (1997) confirmed that in the late '60s and early '70s, the women's revolution sought to explain how women differed from men in certain ways because of the artificial assumptions in behaviors that have been linked to sexual conditions. These stereotypes should be reduced because they were artificial. Language has a great connection with society, so if a change in society occurs, language changes.

According to Sunderland (2000), In the language classroom, no study has been conducted on gendered expression. Even though gender has been extensively studied in foreign language education, relatively few genders and interaction studies still exist in the FL classroom. Although this research will not concentrate on itself, there are some interesting insights about gender, particularly in the EFL attitudes and motivation. Sunderland clarified that there are explanations why the gendered essence of class dialogue depends on curriculum topics. The 
different features can distinguish a foreign language classroom from another gender language subject, as, for example, there are used in the language classroom at least two languages, there is typically much more talk and the teacher may try to talk smaller than students to give students more opportunity to talk (Sunderland, 2000). She claimed that this is why it is probably different when asked of the language classrooms that the response to the question "no topic-specific" such as "Does the teacher pay more attention to girls or boys?" should be provided.

In considering gender in the EFL classroom, Durán (2011) suggested that teachers need to be kept informed of problems such as gender, how they can manifest themselves and how they can be treated. In this way, they will be more attentive and monitored as language teachers and prevent their discrepancies in treatment. It is also important for them to understand how gender interactions exclude students and how language tends to replicate or strengthen behaviors allowing inequality and feelings to arise.

\section{RESEARCH METHODOLOGY}

The research design used qualitative and quantitative approaches that provide various research perspectives concerning the students' attitudes and motivation toward English language teaching based on gender differences. Qualitative and quantitative approaches are for methodological triangulation because the types of data conducted are qualitative and quantitative.

There were 70 students from a state junior high school in Banyumas Regency, Central Java, participating in this research. The researchers excluded six participants because of the zig-zag pattern or giving no responses. More than half of the participants were female students (55\%). Half of the participants were about 15 and 16 years.

Table 1

Participants Description

\begin{tabular}{llrr}
\hline \multicolumn{1}{c}{ Aspect } & \multicolumn{1}{c}{ Frequency } & Percent \\
\hline $\begin{array}{l}\text { Survey } \\
\text { Gender }\end{array}$ & (n) 64 & \\
& Male & 35 & \\
& Female & 29 & $45 \%$ \\
Age & & & \\
& Less than 12 & 6 & $9 \%$ \\
& $13-14$ & 24 & $38 \%$ \\
\hline
\end{tabular}




\begin{tabular}{llrr}
\hline & $15-16$ & 32 & $50 \%$ \\
\multirow{3}{*}{ Grade } & Over 16 & 2 & $3 \%$ \\
& & & \\
& Seventh & 17 & $27 \%$ \\
& Eighth & 25 & $39 \%$ \\
& Ninth & 22 & $34 \%$ \\
\hline
\end{tabular}

The quantitative data gathered used a survey to investigate students' attitudes and motivation toward English language teaching based on their gender differences. The survey employed the Attitude/Motivation Test Battery developed by Gardner. The survey included five aspects, namely interest in English (1-10), attitudes toward English learning (11-20), motivational intensity (21-30), desire to learn (31-40), and orientation index (41). The qualitative data were gathered in interviews to explore the gender perspectives on English language learning attitudes and motivation. The researchers chose six students to interview, three male and three female.

In analyzing the data, the survey items were measured using a 4point Likert scale ranging from strongly agree, agree, disagree, and strongly disagree. The researchers did not use the middle answer to avoid difficult interpretations. Then, the researchers employed descriptive and MANOVA using SPSS 17.0 to reveal the effect of gender differences on the students' attitudes and motivation. The result of the reliability test revealed 0.925 so that the test was reliable for the analysis.

Table 2. Reliability Statistics of Survey

\begin{tabular}{|rr|}
\hline Cronbach's Alpha & N of Items \\
\hline .925 & 41 \\
\hline
\end{tabular}

The researchers used the first language in delivering the interviews to avoid misunderstanding. The interview results were analyzed using the Miles and Huberman model, including coding the data, verifying the data, and building a conclusion. However, the researchers cross-checked the results of both surveys and interviews.

\section{RESULTS AND DISCUSSION}

\section{Results (Survey Result)}

For preliminary analysis, normality and homogeneity were employed to determine the data were eligible to further analysis. The normality test result using Kolmogorov-Smirnov reached the significance level for four 
aspects of motivation $(>0.05)$. Similar to the normality test result, the test of homogeneity of variances revealed the significance level at higher than 0.05 (table 3). Both results performed that the data were distributed normally, homogenous, and eligible for inferential statistics.

Table 3. Normality and Homogeneity Tests

\begin{tabular}{|c|c|c|c|c|c|c|c|}
\hline \multirow{2}{*}{ Aspects } & \multirow{2}{*}{ Gender } & \multicolumn{3}{|c|}{$\begin{array}{l}\text { Kolmogorov- } \\
\text { Smirnov }^{\mathrm{a}}\end{array}$} & \multicolumn{3}{|c|}{$\begin{array}{c}\text { Test of Homogeneity } \\
\text { of Variances }\end{array}$} \\
\hline & & Statistic & $\mathrm{df}$ & Sig. & $\begin{array}{l}\text { Levene } \\
\text { Statistic }\end{array}$ & df1 df2 & Sig. \\
\hline \multirow{2}{*}{$\begin{array}{l}\text { Interest } \\
\text { English }\end{array}$} & n Male & .105 & 35 & $.200^{*}$ & .921 & 162 & .341 \\
\hline & Female & .160 & 29 & .055 & & & \\
\hline \multirow{2}{*}{$\begin{array}{l}\text { Attitudes toward } \\
\text { English Learning }\end{array}$} & d Male & .146 & 35 & .056 & .172 & 162 & .680 \\
\hline & Female & .152 & 29 & .084 & & & \\
\hline \multirow{2}{*}{$\begin{array}{l}\text { Motivational } \\
\text { Intensity }\end{array}$} & Male & .101 & 35 & $.200^{*}$ & .054 & 162 & .818 \\
\hline & Female & .136 & 29 & .182 & & & \\
\hline \multirow[t]{2}{*}{ Desire to Learn } & Male & .138 & 35 & .091 & .409 & 162 & .525 \\
\hline & Female & .109 & 29 & $.200^{*}$ & & & \\
\hline
\end{tabular}

Table 4 described the mean difference scores of the result between male and female students. The male students tend to have lower mean scores in every aspect of attitudes and motivation than female students. Even in the attitude toward English learning, the male students got an average low mean score $(\mathrm{M}=2.98, \mathrm{SD}=0.25)$. The male students who got the highest mean score were in the aspect of motivational intensity. The female students also revealed the highest score in this aspect. It indicated that they have moderate-high motivation to learn English in terms of tasks done for a classroom assignment, plans to use, and study the language, although they have a moderate low attitude to learn English. However, overall the students in this school have a moderate-high level of attitude and motivation toward English learning (male $=3.06$, female $=3.32$ ).

Table 4. Descriptive Statistics of Gender-based Attitudes and Motivation of the Students

\begin{tabular}{lllrr}
\hline Aspects & Gender & N & Mean & \multicolumn{1}{c}{ Std. Dev. } \\
\hline Interest in English & Male & 35 & 3.00 & 0.27 \\
\cline { 2 - 5 }
\end{tabular}


Agus Husein As Sabiq, et.al: Investigating Gender Differences on the Students' Attitudes and Motivation toward English Learning - 245

\begin{tabular}{lllll}
\cline { 2 - 5 } & Female & 29 & 3.24 & 0.22 \\
\hline Attitudes toward & Male & 35 & 2.98 & 0.25 \\
\cline { 2 - 5 } English Learning & Female & 29 & 3.25 & 0.24 \\
\hline Motivational & Male & 35 & 3.23 & 0.41 \\
\cline { 2 - 5 } Intensity & Female & 29 & 3.48 & 0.42 \\
\hline Desire to Learn & Male & 35 & 3.02 & 0.35 \\
\cline { 2 - 5 } & Female & 29 & 3.30 & 0.38 \\
\hline
\end{tabular}

The Multivariate analysis of variance was used to reveal the significance level $(<0.05)$ in all aspects. It indicated that gender influenced all aspects of students' attitudes and motivation toward English learning. However, the male students tend to have low levels of attitudes and motivation compared to the female students.

Table 5. The Result of Multivariate Tests

\begin{tabular}{llrrrrr}
\hline & & \multicolumn{5}{c}{ Hypothesi } \\
\hline \multirow{2}{*}{ Eender } & Value & \multicolumn{1}{c}{ F } & s df & Error df & Sig. \\
\cline { 2 - 7 } & Pillai's Trace & .293 & $6.124^{\mathrm{a}}$ & 4.000 & 59.000 & .000 \\
\cline { 2 - 7 } & Wilks' Lambda & .707 & $6.124^{\mathrm{a}}$ & 4.000 & 59.000 & .000 \\
\cline { 2 - 7 } & Hotelling's Trace & .415 & $6.124^{\mathrm{a}}$ & 4.000 & 59.000 & .000 \\
\cline { 2 - 7 } Largest & .415 & $6.124^{\mathrm{a}}$ & 4.000 & 59.000 & .000 \\
& $\begin{array}{l}\text { Roy's } \\
\text { Root }\end{array}$ & & & & & \\
\hline
\end{tabular}


Table 6. Tests Results of Between-Subjects Effects

\begin{tabular}{|c|c|c|c|c|c|c|}
\hline Source & Dependent Variable & $\begin{array}{l}\text { Type III Sum } \\
\text { of Squares }\end{array}$ & Df & $\begin{array}{l}\text { Mean } \\
\text { Square }\end{array}$ & $\mathrm{F}$ & Sig. \\
\hline \multirow[t]{4}{*}{ Gender } & Interest in English & .929 & 1 & .929 & 14.533 & .000 \\
\hline & $\begin{array}{l}\text { Attitudes toward } \\
\text { English Learning }\end{array}$ & 1.201 & 1 & 1.201 & 19.657 & .000 \\
\hline & $\begin{array}{l}\text { Motivational } \\
\text { Intensity }\end{array}$ & .978 & 1 & .978 & 5.510 & .022 \\
\hline & Desire to Learn & 1.260 & 1 & 1.260 & 9.207 & .004 \\
\hline
\end{tabular}

In the aspect of the orientation index, the participants have presented six possible reasons for studying English. Three responses stressed instrumental motivation and three stressed integrative motivation. The result revealed that the students tend to have instrumental motivation (79\%), which meant that they learned English to improve their academic status, get a job, or pass the exam. $76 \%$ of male students had instrumental motivation, and $83 \%$ of female students also had instrumental motivation.

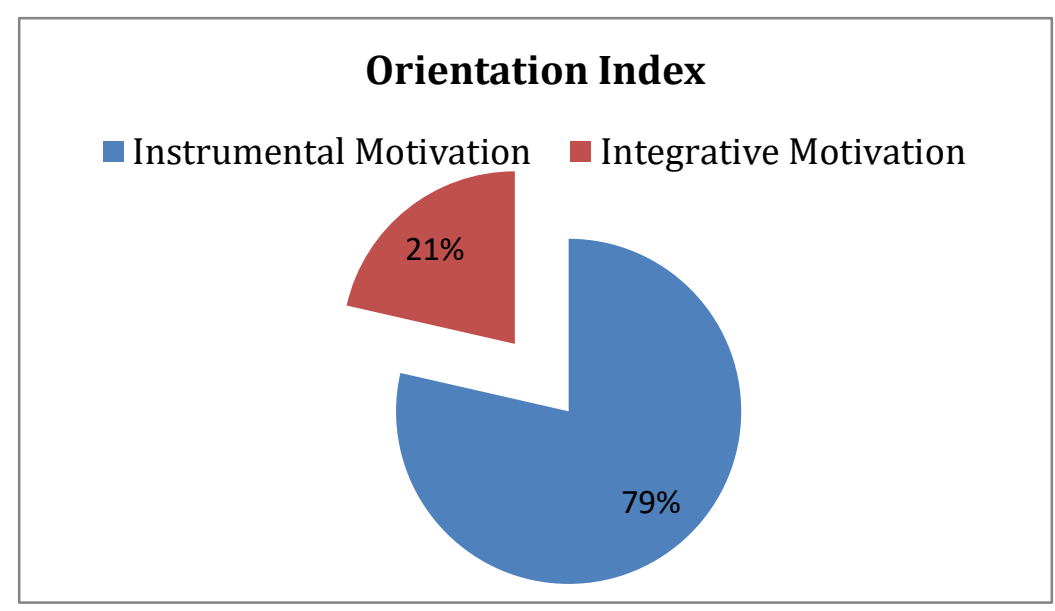

Figure 1. Percentage of Students' Orientation Index

\section{Interview Results}

The researchers did the interviews with six students, three males, and three females. The interviews explored deeper data and information concerning the students' attitudes and motivation towards English 
Agus Husein As Sabiq, et.al: Investigating Gender Differences on the Students' Attitudes and Motivation toward English Learning - 247

learning based on their gender. Besides, the qualitative analysis was for strengthening the quantitative results of the survey.

At the beginning of the interviews, both male and female interviewees agreed that English is a medium of communication across the world community. They showed positive attitudes toward English. However, a male student felt that English is like another subject so that he was not excited to learn English, although he agreed with his friends that English is one of the essential subjects to learn. Furthermore, he explained that English learning in the class only learned basic English, not using it properly in real-life communication. At the same time, the female students reported that they liked English because of their future academic goals and careers. The other male students had a simple reason that they would be cool when mastering English.

Both male and female students reported that vocabulary mastery and pronunciation were the most challenging skill to master. Student 6 (female) said, "The difficulty is when pronouncing the words, writing, and memorizing vocabulary." However, they responded that they felt excited when studying and living in a native speaker community. Student 2 stated that he would be fluent in English if he lives in English speaking community because of habituation. To get deeper data about their attitudes toward the target language community, students' attitudes when meeting or speaking with native speakers were crucial to delivering. They realized that they were still limited to speaking, but they showed efforts to improve their proficiencies. Even student 1 has experienced speaking with a native speaker and said that he could get direct exposure to understand what the native said.

Two male students reported that they would study after school when they have a good mood and one of these two students said that he usually goes to help his parents work in the ricefield so that he rarely studies after school. At the same time, all-female students studied English after school if they had homework from their teacher. Student 1 (male) had a different experience than the others in which he kept studying English after school with his father, who worked with a native speaker. Furthermore, he seemed to be a diligent student that he never skipped submitting the task on time like female students. Contrastly, two male students said that they sometimes skipped doing homework for some reason. However, they agreed that asking the teacher or translating by Google Translate was the two things they would do to handle English learning difficulties.

In the English classroom, the students stated that they will always have an effort to engage in the classroom activities, for example, by answering the teacher's question using English as much as possible. 
However, two male students preferred that the teacher used Bahasa Indonesia as language instruction, in contrast with the others who preferred that the teacher used English more. Student 5 (female) said, "I prefer that the teacher speaks as much English as possible and interspersed with Indonesian when needed." Although most of them preferred English to be language instruction, two males and two females stated that they felt the anxiety to speak English in the classroom. Student 6 explained, "Rarely. I am scared to make an error". Only two students (student 1 and student 4) claimed that they were confident to speak English in front of the class.

The last question of the interview was to explore the students' motivating factors in learning English. They responded with various answers. Student 1 and student 4 tend to have an integrative motivation that they needed English to communicate with the international community and to live in other countries. Student 1 said:

"English is not to look cool, but English is to communicate too. Besides,

for me English is interesting, and English makes it easier for me to talk to foreigners such as tourists."

The other students showed that they have instrumental motivation in learning English. They believed that English is essential for their future careers besides an international language. As student 6 said, "Because English is an international language and I believe it will come in handy one day when I am looking for a job."

\section{Discussion}

This study aimed to investigate the student's attitudes and motivation toward English language learning based on their differences and to determine the level of attitudes and motivation. The participants' percentage was pretty balanced between male (55\%) and female (45\%) students from a state junior high school. The grade and ages were also various that gave different perspectives on the analysis. However, this study focused on the students' gender differences in line with their attitudes and motivation.

The survey results revealed a significant difference between male and female students in the attitudes and motivation toward EFL learning. The female students have had higher average scores on the four constructs of attitudes and motivation. The male students got the lowest average score on the construct of attitudes toward learning English (2.98). The interview with one of the male students supported the survey 
results that they were not excited about English learning because of rarely used in real-life communication. Conveying a similar instrument (AMTB), Akram \& Ghani (2013) found different findings that there was no significant difference between male and female Pakistani students' attitudes and motivation toward English.

For many teachers, designing EFL classroom activities full of exposure is challenging to improve students' motivation. It was challenging to achieve the English language to be addressed as teachers' lessons required by the students. The instructors with their "mixed language" seemed to overtake the class and the students seemed to stay quiet (Yulia, 2013) even though providing enough exposure had a significant impact on second or foreign language acquisition (Al-Zoubi, 2018). Besides, the students' positive attitude and high motivation will show their good discipline and eventually achieve valuable learning results (Astuti, 2020). Therefore, less practice and limited exposure would make the students have limited comprehensible input for language acquisition.

Both survey and interview results showed that the students have a high interest in English and a good attitude to the target language community. Both male and female students have moderately high average scores in the construct of interest in English, motivational intensity, and desire to learn. However, female students have higher scores than male students in these three aspects. This finding was different from Gajalakshmi (2013), who found that male senior high school had higher attitude and motivation than female students but in line with Purbandari et al. (2018), who found that both male and female students have high positive attitudes and motivation toward learning to speak. The interviews also showed that they expected to communicate directly with the native speakers if they have an opportunity. They have a strong desire to practice their English skills with native speakers, although their proficiency was still limited. Thus, allowing practicing reallife communication and providing authentic materials and exposures became key points for improving meaningful learning experiences. Widyastuti (2017) proposed the combination of authentic materials and automatic strategies for English learning. The authentic materials will make the learning experience enjoyable and eradicate repetition as the information and subjects can be searched online to make it more immersive and visually useful. The automaticity principle will solve students' dilemma who need to remember words that make them bored and forget words quickly. The other advantage is that students can expose 
the actual vocabulary used in a true sense and promote interactions in reality.

Gender differences interrelated with different ages raised different styles of the students thinking (Qian, 2015). Male students tend to think logically, pragmatically, and relaxed. As seen from the male students' interviews, they often paid no attention to learning after school or doing homework. They would do the task when they have a good mood or under pressure from the teacher. Besides, environmental factors also affected the male students to be responsible as a boy as reported by one male student who reported that he should help his parents work in the rice field.

Language instruction preferences in the English classroom showed different learning styles, paying attention, memory, and thinking ability (Qian, 2015). Thus, in language learning, these characteristics would be the basic consideration for developing learning activities, especially providing comprehensible input for language acquisition. As Sabiq (2020) concluded that teachers' perceptions of the most suitable language instruction implementation, instructional methods, learning materials, and media can lead them to facilitate learning adequately in improving students' English proficiency. By using the right teaching strategies, students can fix wrong learning behaviors, improve selflearning instruction, and enhance foreign language learning performance at any time. On the other hand, learning media used can also improve students' motivation to learn. Some researchers reported that male students tend to be visual learners, and females tend to be auditory learners (Astuti et al., 2020; Nurkholida, 2016; Viriya \& Sapsirin, 2014). Therefore, the combination of visual and auditory media can improve both male and female students' motivation (As Sabiq, 2018; Brian et al., 2017; Fauziah et al., 2018; Stasya et al., 2018).

The findings confirmed that both male and female students have instrumental motivation (76\% male students, $83 \%$ female students). They were motivated to learn English to improve their academic status, get a job, or pass the exam. However, male students have higher integrative motivation than female students. Unlike Al Harthy (2017), he found that female students expressed higher integrative motivation than males.

A positive attitude leads to positive behavior in terms of learning courses and a desire to understand the heart of learning. Motivation for learning is the driving force behind the hard work of students. Therefore, the teacher must consider the essence of the students' attitudes and 
Agus Husein As Sabiq, et.al: Investigating Gender Differences on the Students' Attitudes and Motivation toward English Learning - 251

motivation in designing classroom activities, developing meaningful learning, and providing more language acquisition exposure.

\section{CONCLUSION}

In this study, both male and female students expressed positive attitudes and moderately high motivation toward English language teaching. Female students have a higher average score of attitudes and motivation than males. However, male students have higher integrative motivation than females. The students confirmed that they were motivated in English learning for educational purposes, future careers, and few of them were motivated to engage in the target language community. Students' socio-psychological backgrounds may lead them to construct their beliefs toward target language learning and community as well as motivation to learn.

Based on these outlined findings, the teachers are encouraged to consider the students' psychological backgrounds in developing learning materials, instructional media, and teaching strategies according to the students' attitudes, motivation, learning preferences, and styles. This study is limited to a state school and limited participants. Therefore, the researchers recommend the other researchers for future research to explore more about the students' attitudes and motivation based on their differences (gender, age, aptitude, learning styles), school locality, and management.

\section{REFERENCES}

Abu-rabia, S. (1997). Gender Differences in Arab Students' Attitudes Toward Canadian Society and Second Language Learning. The Journal of Social Psychology, 137(1), 125-128. https://doi.org/10.1080/00224549709595420

Ahmad, I. S., Abdullah, H., \& A Ghani, M. F. (2014). Attitudes and Motivation toward Learning the English Language among Students from Islamic Education System Background: Exploring the Views of Teachers. Journal of Education and Learning (EduLearn), 8(3), 195208. https://doi.org/10.11591/edulearn.v8i3.262

Ajzen, I., \& Fishbein, M. (2000). Attitudes and the Attitude-Behavior Relation: Reasoned and Automatic Processes. European Review of Social Psychology, 11(1), 1-33. https://doi.org/10.1080/14792779943000116 
Akdemir, A. S. (2019). Age, Gender, Attitudes, and Motivation as Predictors of Willingness to Listen in L2. Advances in Language and Literary Studies, 10(4), 72. https://doi.org/10.7575/aiac.alls.v.10n.4p.72

Akram, M., \& Ghani, M. (2013). Gender and language learning motivation. Academic Research International, 4(2), 536-540.

Al-Zoubi, S. M. (2018). The Impact of Exposure to the English Language on Language Acquisition. Journal of Applied Linguistics and Language Research, 5(4), 151-162.

Al Harthy, S. R. (2017). English Language Motivation between Gender and Cultures. Journal of Educational and Social Research, 7(2), 123-132. https://doi.org/10.5901/jesr.2017.v7n2p123

Aldosari, H. S. (2014). The Entwined Effects of Attitude, Motivation, and Gender on EFL Learning: A Correlation Study. Studies in Literature and Language, 8(1), 1-5. https://doi.org/10.3968/j.sll.1923156320140801.4183

As Sabiq, A. H. (2018). Improving Students' Motivation and Reading Skills in ELT through Audio-Visual Media. Dikes, 25(1), 57-68. https://doi.org/10.21831/diksi.v25i1.16007

As Sabiq, A. H. (2020). Localized English for Ngapak Javanese Speakers as Language Instruction. ENGLISH FRANCA : Academic Journal of English Language and Education, 4(2), 85-114. https://doi.org/10.29240/ef.v4i2.1818

Astuti, D., Sarwanto, \& dan Chumdari. (2020). The Effect of Gender on Student Learning Style in Class IV, SD N Mangkuyudan. 3rd International Conference on Learning Innovation and Quality Education (ICLIQE 2019), 397(Icliqe 2019), 672-678. https://doi.org/10.2991/assehr.k.200129.084

Astuti, P. (2020). Relationship Between Motivation and Discipline of Students to Student Learning Outcomes Class XI Vocational High School. ENGLISH FRANCA : Academic Journal of English Language and Education, 4(1), 1-16. https://doi.org/10.29240/ef.v4i1.951

Bacon, S. M. (1992). The Relationship between Gender, Comprehension, Processing Strategies, and Cognitive and Affective Response in Foreign Language Listening. The Modern Language Journal, 76(2), 160-178. https://doi.org/10.2307/329769

Bidin, S., Jusoff, K., Aziz, N. A., Salleh, M. M., \& Tajudin, T. (2009). 
Agus Husein As Sabiq, et.al: Investigating Gender Differences on the Students' Attitudes and Motivation toward English Learning - 253

Motivation and Attitude in Learning English among UiTM Students in the Northern Region of Malaysia. English Language Teaching, 2(2), 16-20. https://doi.org/10.5539/elt.v2n2p16

Brian, I. . P. F. C. K., Saputra, I. N. P. H., \& Wdhanti, N. K. (2017). The Effect of Teaching Using Audiovisual (Video) Media, on Seventh Grade Students' Listening Comprehension at SMP Negeri 1 Mengwi Academic Year 2017/2018. Jurnal Pendidikan Bahasa Inggris Undiksha, 5(2), 1-11. https://doi.org/http://dx.doi.org/10.23887/jpbi.v5i2.14869

Butler, J. (1989). Gender Trouble: Feminism and the Subversion of Identity. Routledge.

Castaneda-Pena, H. (2008). Positioning masculinities and femininities in preschool EFLl1 education. Signo y Pensamiento, 27, 314-326.

Choy, S. C., \& Troudi, S. (2006). An Investigation into the Changes in Perceptions of and Attitudes Towards Learning English in a Malaysian College. The International Journal of Teaching and Learning in Higher Education, 18(2), 120-130.

Cook, D. A., \& Artino Jr, A. R. (2016). Motivation to learn: an overview of contemporary theories. Medical Education, 50(10), 997-1014. https://doi.org/10.1111/medu.13074

Csizer, K., \& Dornyei, Z. (2005). The Internal Structure of Language Learning Motivation and Its Relationship with Language Choice and Learning Effort. The Modern Language Journal, 89(1), 19-36. https://doi.org/10.1111/j.0026-7902.2005.00263.x

Dardjowidjojo, S. (2000). English Teaching in Indonesia. EA Journal.

Daskalovska, N., Gudeva, L. K., \& Ivanovska, B. (2012). Learner Motivation and Interest. Procedia - Social and Behavioral Sciences, 46, 11871191. https://doi.org/10.1016/j.sbspro.2012.05.272

Dörnyei, Z. (2003). Attitudes, Orientations, and Motivations in Language Learning: Advances in Theory, Research, and Applications. Language Learning, 53(S1), 3-32. https://doi.org/10.1111/1467-9922.53222

Durán, N. C. (2011). Exploring gender differences in the EFL classroom. Colombian Applied Linguistics Journal, 8, 123. https://doi.org/10.14483/22487085.174

Elliott, S. N. (2000). Educational Psychology: Effective Teaching, Effective Learning. McGraw-Hill. 
Erwin, P. (2001). Attitudes and Persuasion. Psychology Press. https://books.google.co.id/books?id=iG2ypQ3eW50C

Fakeye, D. O. (2010). Students' Personal Variables as Correlates of Academic Achievement in English as a Second Language in Nigeria. Journal of Social Sciences, 22(3), 205-211. https://doi.org/10.1080/09718923.2010.11892803

Fatiha, M., Sliman, B., Mustapha, B., \& Yahia, M. (2014). Attitudes and Motivation in Learning English as a Foreign Language. International Journal of Arts and Sciences, 7(3), 117-128.

Fauziah, F., Rachmawati, E., \& Misbahudin. (2018). Male-female EFL Students' Perception on the Use of Audio-Visual Aids to Improve Their Vocabulary Mastery. Journal of Applied Linguistics and Literacy, 2(1), 25-39.

Feng, R., \& Chen, H. (2009). An Analysis on the Importance of Motivation and Strategy in Postgraduates English Acquisition. English Language Teaching, 2(3), 93-97. https://doi.org/10.5539/elt.v2n3p93

Filgona, J., Sakiyo, J., Gwany, D. M., \& Okoronka, A. U. (2020). Motivation in Learning. Asian Journal of Education and Social Studies, 10(4), 1637. https://doi.org/10.9734/ajess/2020/v10i430273

Flotow, L. von. (1997). Translation and Gender. University of Ottawa Press. http://www.jstor.org/stable/j.ctt1cn6t97

Frijters, J. C., Brown, E., \& Greenberg, D. (2019). Gender Differences in the Reading Motivation of Adults with Low Literacy Skills. In D. Perin (Ed.), The Wiley Handbook of Adult Literacy (pp. 63-87). https://doi.org/https://doi.org/10.1002/9781119261407.ch3

Gajalakshmi. (2013). High School Students ' Attitude towards Learning English Language. International Journal of Scientific and Research Publications, 3(9), 1-7.

Gardner, R. (1985). The Attitude/Motivation Test Battery: Technical Report (Issue July 2013).

Gardner, R. (2006). The socio-educational model of Second Language Acquisition. EUROSLA Yearbook, 6, 237-260. https://doi.org/10.1075/eurosla.6.14gar

Gardner, R.C., Lalonde, R. N., \& Moorcroft, R. (1985). The Role of Attitudes and Motivation in Second Language Learning: Correlational and Experimental Considerations. Language Learning, 35(2), 207-227. 
Agus Husein As Sabiq, et.al: Investigating Gender Differences on the Students' Attitudes and Motivation toward English Learning - 255

https://doi.org/10.1111/j.1467-1770.1985.tb01025.x

Gardner, Robert C. (2005). Attitude / Motivation Test Battery: International AMTB Research Project. In The University of Western Ontario.

Gömleksiz, M. N. (2010). An evaluation of students' attitudes toward English language learning in terms of several variables. Procedia Social and Behavioral Sciences, 9, 913-918. https://doi.org/10.1016/j.sbspro.2010.12.258

Gusmuliana, P., Apriani, E., \& Karolina, A. (2020). ISLAMIC FEFAC AS AN INTERESTING LEARNING MEDIA TO IMPROVE STUDENTS'ENGLISH ABILITY AND DEVELOP THEIR CHARACTER VALUES IN MAN REJANG LEBONG. ISLAMIC FEFAC AS AN INTERESTING LEARNING MEDIA TO IMPROVE STUDENTS'ENGLISH ABILITY AND DEVELOP THEIR CHARACTER VALUES IN MAN REJANG LEBONG, 1(01), 36-44.

Gusmuliana, P., Apriani, E., \& Syafryadin, S. (2021). Improving Students Speaking Motivation by Using Role Play Technique at Institute Islamic in Indonesia.

Heinzmann, S. (2009). "Girls Are Better at Language Learning Than Boys": Do Stereotypic Beliefs about Language Learning Contribute to Girls' Higher Motivation to Learn English in Primary School? Bulletin Suisse de Linguistique Appliquee, 89(spring), 19-36.

Holland, R. W., Verplanken, B., \& Van Knippenberg, A. (2002). On the nature of attitude-behavior relations: the strong guide, the weak follow. European Journal of Social Psychology, 32(6), 869-876. https://doi.org/https://doi.org/10.1002/ejsp.135

Kara, A. (2009). The Effect of a 'Learning Theories' Unit on Students' Attitudes Toward Learning. Australian Journal of Teacher Education, 34(3), 100-113. https://doi.org/10.14221/ajte.2009v34n3.5

Karthikeyan, M. (2017). ETHICS, INTEGRITY AND APTITUDE EBOOK. McGraw-Hill Education.

Kirkpatrick, A. (2011). English as an Asian lingua franca and the multilingual model of ELT. Language Teaching, 44(2), 212-224. https://doi.org/10.1017/S0261444810000145

Litosseliti, L. (2006). Gender and Language Theory and Practice. Hodder Arnold. https://doi.org/10.4324/9780203784792

Murtafi'ah, B., \& Putro, N. H. P. S. (2020). Gender differences in santri 
reading attitude and motivation. EduLite: Journal of English Education, Literature and Culture, 5(2), 251-262. https://doi.org/10.30659/e.5.2.251-262

Niaz, S., Memon, N., \& Umrani, S. (2018). Gender Differences in Motivation Level for Learning English as an L2. 46(46), 27-34.

Nurkholida, E. (2016). Gender Differences on Learning Styles and Learning Strategies of English Department Students of Stain Kediri. Realita, 14(2), 187-197.

Petty, R. E., Tormala, Z. L., \& Rucker, D. D. (2008). Resisting persuasion by counterarguing: An attitude strength perspective. In J. T. Jost, M. R. Banaji, \& D. A. Prentice (Eds.), Perspectivism in social psychology: The yin and yang of scientific progress. (Vol. 49, pp. 37-51). American Psychological Association. https://doi.org/10.1037/10750-004

Purbandari, P., Rachmawati, E., \& Febriani, R. B. (2018). Male And Female Students' Attitudes toward English Vocabulary Mastery in Learning Speaking (A Survey Study at one of MA Islamic Boarding School in Tasikmalaya). Journal of Applied Linguistics and Literacy, 2(2), 89100.

Qian, W. (2015). A Study of the Influence of Gender Differences on English Learning of Senior High School Students. Higher Education of Social Science, 8(6), 66-69. https://doi.org/10.3968/7173

Reeve, J. (2005). Understanding Motivation and Emotion. Wiley.

Reeve, Johnmarshall. (2016). A grand theory of motivation: Why not? Motivation and Emotion, 40(1), 31-35. https://doi.org/10.1007/s11031-015-9538-2

Rubin, J. (1975). What a Good Language Learners Can Teach Us. TESOL Quarterly, 9(1), 41-51. http://www.jstor.org/stable/3586011

Ruyffelaert, A., \& Hadermann, P. (2012). The impact of age and gender on the learners' motivation and attitudes towards French in secondary education in Flanders. INTED Proceedings, March, 159-165.

Ryan, R. M., \& Deci, E. L. (2000). Intrinsic and Extrinsic Motivations: Classic Definitions and New Directions. Contemporary Educational Psychology, 25(1), 54-67. https://doi.org/https://doi.org/10.1006/ceps.1999.1020

Saeed, M., Iqbal, M., Akhtar, M., \& Saleem, K. (2014). Development of a Scale to Measure English Language Learning Attitude of Secondary 
School Students. Journal of Educational Research, 17(2), 17-42.

Stasya, A., Sari, P., \& Pangaribuan, J. J. (2018). The Combination of TaskBased Learning (TBL) Approach and Audio Visual Aids to Improve Students' Academic Writing Skills. Jurnal Liner, 1(3), 16-28.

Sunderland, J. (2000). Issues of language and gender in second and foreign language education. Language Teaching, 33(4), 203-223. https://doi.org/DOI: 10.1017/S0261444800015688

Viriya, C., \& Sapsirin, S. (2014). Gender differences in language learning style and language learning strategies. Indonesian Journal of Applied Linguistics, 3(2), 77-88. https://doi.org/10.17509/ijal.v3i2.270

Widyastuti. (2017). Authentic Material and Automaticity for Teaching English. REGISTER JOURNAL, Language \& Language Teaching Journals, 10(1), 1-17.

Winke, P. (2005). Promoting Motivation in the Foreign Language Classroom. Clear News, 9(2), 1-12.

Yulia, Y. (2013). Teaching challenges in Indonesia: Motivating students and teachers' classroom language. Indonesian Journal of Applied Linguistics, 3(1), 1-16. https://doi.org/10.17509/ijal.v3i1.186

Zlate, S., \& Cucui, G. (2015). Motivation and Performance in Higher Education. Procedia - Social and Behavioral Sciences, 180 (November 2014), 468-476. https://doi.org/10.1016/j.sbspro.2015.02.146 
258 | ENGLISH FRANCA, Vol. 5, No. 2, 2021 